\title{
INACTIVATION OF THROMBOPLASTIN IN HUMAN BLOOD
}

\author{
By THEODORE H. SPAET ${ }^{1}$ AND EVELYN S. GARNER \\ (From the Department of Medicine, Stanford University School of Medicine, San Francisco, \\ Calif.)
}

(Submitted for publication May 20, 1955; accepted August 31, 1955)

In the course of blood clotting, a potent thromboplastic activity develops, which is no longer present in serum. Biggs, Douglas, and Macfarlane (1) in early studies with the thromboplastin generation test found that prolonged incubation of the generating mixture was accompanied by loss of thromboplastic activity. These investigators suggested that this loss could result either from intrinsic instability of blood thromboplastin or from a neutralization effect. Similar results were obtained by Spurling and King (2), who demonstrated progressive loss of thromboplastin on prolonged incubation when serum was used as the source of plasma thromboplastin component (PTC) in the thromboplastin generation test.

The data to be presented suggest that the thromboplastin formed by blood components is inactivated by a plasma protein contained in the crude albumin fraction.

\section{METHODS AND MATERIALS}

Human and bovine plasmas were obtained from blood to which had been added one-tenth volume of 0.1 molar potassium oxalate.

Barium sulfate adsorbed plasma was prepared as follows : For each cc. of plasma 0.1 cc. of molar $\mathrm{BaCl}_{2}$ was mixed with $0.1 \mathrm{cc}$. of $\mathrm{Na}_{2} \mathrm{SO}_{4}$. The barium sulfate precipitate was washed three times in isotonic saline. The plasma was mixed with the washed barium sulfate, and adsorption allowed to proceed for ten minutes at about $20^{\circ}$ C. The barium sulfate was finally removed by centrifugation.

Human serum was obtained from blood defibrinated with glass beads as described by Biggs and Douglas (3).

Platelet extract was made as follows: A silicone technique was employed throughout. Two liters of oxalated bovine blood were centrifuged for 20 minutes at $1,200 \mathrm{rpm}$ in a Universal PR-1 refrigerated centrifuge kept at $20^{\circ} \mathrm{C}$. The platelet-rich supernatant plasma was then separated, and the platelets were sedimented by centrifugation for one hour at $3,000 \mathrm{rpm}$. The platelets were pooled, and were subjected to three successive suspensions and sedimentations in changes of isotonic saline. The

1 Present address : Montefiore Hospital, New York 67, New York. platelet mass finally obtained was homogenized into 25 cc. of isotonic saline, and diluted to $200 \mathrm{cc}$. with distilled water. This suspension was frozen and thawed twice, and then further homogenized in a Waring Blendor. The particulate matter was removed by centrifugation at 3,000 rpm for 10 minutes, leaving a clear supernatant fluid. This supernatant was frozen at minus $20^{\circ} \mathrm{C}$. in $2 \mathrm{cc}$ aliquots which were thawed as needed.

All coagulation procedures were performed in a water bath at $37^{\circ} \mathrm{C}$.

Recalcification of clotting mixtures was accomplished with 0.025 molar calcium chloride.

The thromboplastin generation test was derived from the method of Biggs and Douglas (3), and was performed as follows: Fifteen hundredths cc. each of platelet extract, barium sulfate adsorbed plasma, and serum were mixed, and allowed to incubate for one minute, at which point 0.15 cc. of $\mathrm{CaCl}_{2}$ was added. This mixture was then assayed for thromboplastic activity at designated intervals after recalcification. This assay of thromboplastic activity was accomplished by adding $0.1 \mathrm{cc}$. of the mixture to $0.1 \mathrm{cc}$. of untreated bovine plasma which had been recalcified exactly 15 seconds previously with 0.1 cc. of $\mathrm{CaCl}_{\text {s }}$.

\section{RESULTS}

Preliminary studies were undertaken to determine whether the loss of thromboplastic activity in the thromboplastin generation test was due to instability of the thromboplastin itself or whether it resulted from the inactivating effect of some plasma components. To distinguish between these possibilities, the behavior of the generating mixture was studied with two concentrations of reacting ingredients. In one the barium sulfate plasma and serum were used undiluted; in the other the serum was diluted to 10 per cent and the plasma to 20 per cent with isotonic saline. The concentration of the platelet extract was held constant. In each case serial determinations of thromboplastic activity were obtained for over an hour. The results of these studies are shown in Figure 1. Both mixtures attained a comparable degree of thromboplastic activity after four minutes of incubation. However, it is evident that the mixture containing the undiluted ingredients showed 


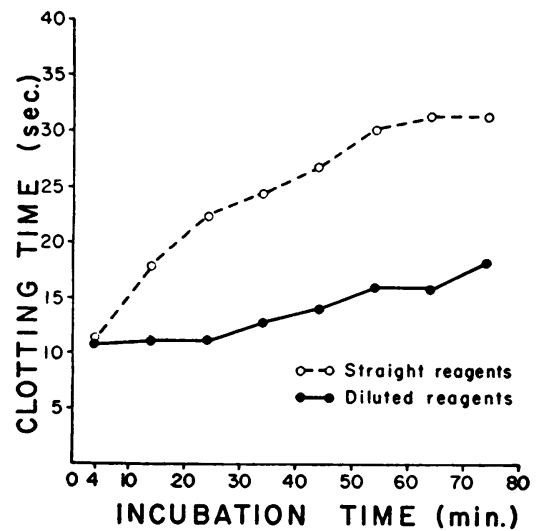

Fig. 1. Effect of Reagent Concentration on the Loss of Thromboplastic Activity in the Thromboplastin Generation Test

a more rapid and more profound loss of thromboplastic activity after further incubation. These findings indicate that the loss of thromboplastic activity was due to inactivation by some component found in blood. Accordingly, an assay method was devised to measure the ability of a specimen to inactivate blood thromboplastic activity.

\section{The thromboplastin inactivation test}

After a series of preliminary investigations, the following procedure was found to give the most reproducible results: The basic steps are similar to those described for the thromboplastin generation test, with a few additions and modifications. The initial incubating mixture consists of equal volumes of 10 per cent barium sulfate beef plasma, 10 per cent human serum (both diluted with isotonic saline), and platelet extract. One minute after these reagents are mixed an additional volume of $\mathrm{CaCl}_{2}$ solution is added. Four minutes after recalcification the mixture is assayed for thromboplastic activity as above. At five minutes further thromboplastin generation is stopped by decalcification and the test specimen is added to the generating mixture. This test specimen consists of 3 volumes of the unknown solution mixed with 1 volume of 0.025 molar sodium citrate. One volume of test specimen is added to one volume of generating mixture. One minute, and 30 minutes after the addition of the test specimen the mixture is tested for thromboplastic activity. Each time a series of thromboplastin inactivation tests is run, a blank is substituted for the test specimen in the five-minute addition. This blank consists of citrated saline instead of unknown solution, and serves as a check on loss of thromboplastic activity from reactions in the original generating mixture. The essential steps in the thromboplastin inactivation test are shown diagrammatically in Figure 2.

The thromboplastin inactivation test was performed on sera obtained from healthy volunteers among the hospital staff and medical students. Figure 3 summarizes the results obtained. There is slight loss of thromboplastic activity in the saline blank, which results partly from dilution, and probably from the action of the initial reagents as well. The normal sera show a strikingly increased ability over the saline control to elicit thromboplastin inactivation. This inactivation is progressive, increasing with greater duration of incubation. As judged by dilution curves of the original generating mixture (3), more than 90 per cent of the thromboplastic activity formed is inactivated after thirty minutes of incubation with serum. The curve obtained when serial dilutions of serum are used in the thromboplastin inactivation assay is shown in Figure 4. The amount of thromboplastin inactivated appears to be roughly proportional to the concentration of serum. Oxalated plasma has the same ability to inactivate thromboplastin as has serum.

\section{Properties of the thromboplastin inactivator}

Preliminary manipulation of serum showed that the thromboplastin inactivator is stable to storage

\section{THE THROMBOPLASTIN INACTIVATION TEST}

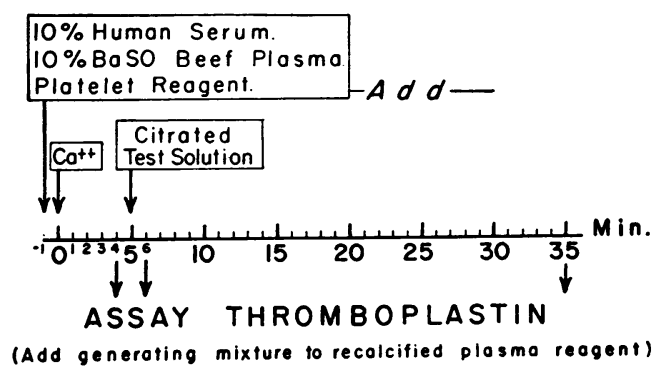

Figure 2 


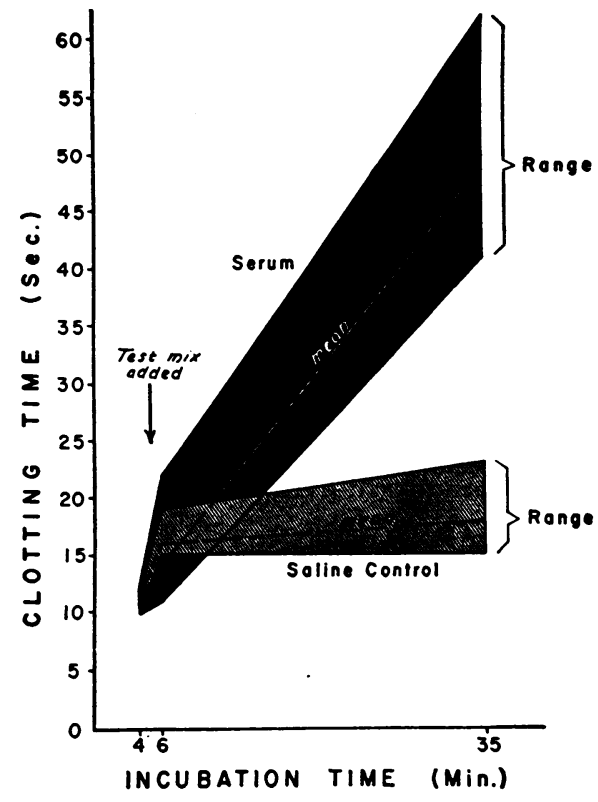

Fig. 3. Thromboplastin Inactivation by Normal Human Sera as Compared to Saline Controls

both at room and refrigerator temperatures for at least one week. It was present undiminished in serum stored for over one month at $-20^{\circ} \mathrm{C}$., and in plasma that had been lyophilized. It withstood heating at $56^{\circ} \mathrm{C}$. for 30 minutes in serum, but was partially destroyed at a temperature of $60^{\circ} \mathrm{C}$. after 10 minutes of incubation. It was not removed from serum by barium sulfate or kaolin, nor could it be extracted with repeated ethyl ether treatment. The thromboplastin inactivator was not removed from serum by dialysis against isotonic saline.

Commercially prepared Cohn fractions of human plasma were obtained in dried, powdered form. $^{2}$ These fractions were dissolved in isotonic saline so that the protein concentration of each was approximately equivalent to its normal physiological level. The solutions of the various fractions were then tested for thromboplastin inactivator activity. As seen in Figure 5, only fraction $\mathrm{V}$ had significant activity, and this activity appeared to represent a quantitative yield of the original plasma content. Full activity was present in outdated lots of liquid Red Cross salt-free albumin stored at refrigerator temperature, and was found in several different lots of "crude" fraction

2 Kindly provided by Dr. Fred Johnson of the Cutter Laboratories, Berkeley, Calif.
V. Two lots of purified fraction V were also tested. In these preparations, certain trace proteins of fraction VI had been removed, leaving almost pure albumin. Although the protein content of these solutions was the same as that used in testing crude fraction $\mathrm{V}$, the purified fractions were inert with respect to thromboplastin inactivator. These data indicate that the thromboplastin inactivation effect is not the result of a nonspecific protein reaction. Moreover, the thromboplastin inactivator is evidently not albumin per se. This view is further confirmed by a study of sera from two patients suffering from the nephrotic syndrome. Despite marked reduction of albumin in these sera, as shown by paper electrophoresis, both had normal thromboplastin inactivator activity.

An attempt was made to separate thromboplastin inactivator from albumin by electrophoresis convection (4). A 4 per cent solution of fraction $\mathrm{V}$ was prepared in a citric acid-phosphate buffer solution of 0.1 ionic strength and $\mathrm{pH} 4.8$. The run was performed at room temperature for 24 hours at 0.9 millivolt in a Beckman electrophoresis convection apparatus. Partial purification of the albumin resulted from this single run, with the majority of alpha ${ }_{1}$ globulin concentrated in the upper chamber of the apparatus. The throm-

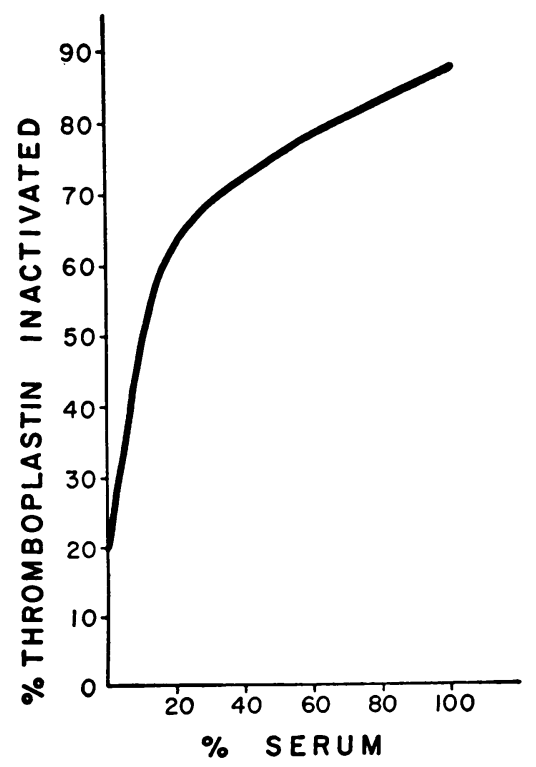

Fig. 4. The Effect of Dilution on the Ability of Normal Human Serum to Inactivate ThromboPLASTIN 


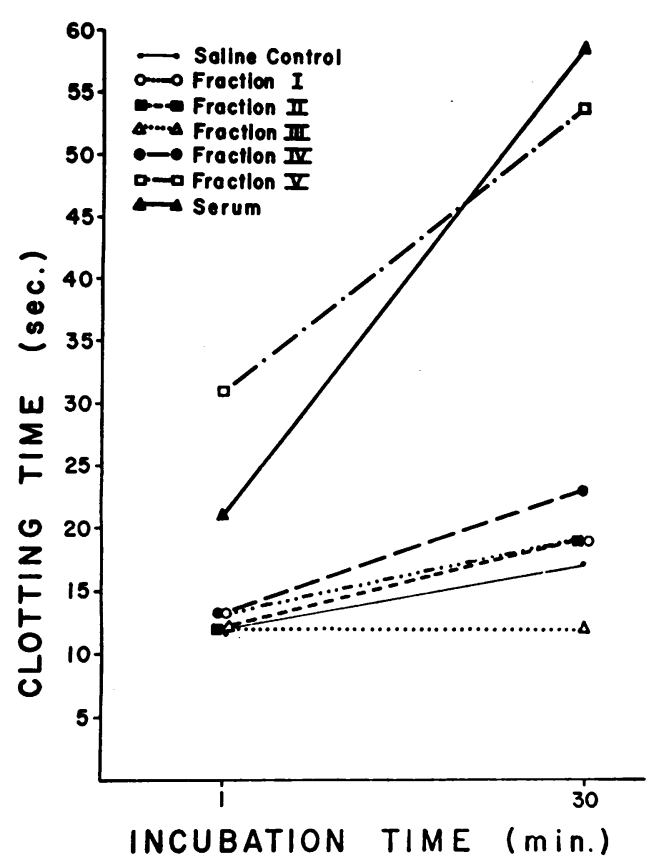

Fig. 5. Thromboplastin Inactivation by Fractions of Normal Human Plasma

boplastin inactivator activity was found in the bottom chamber together with the albumin.

\section{Thromboplastin inactivator in disease}

To date about 20 patients with a variety of disorders have been studied. This group has included at least two with established thrombo-embolic conditions. No consistent alterations of serum thromboplastin inactivator have been detected as yet, except in the case of one patient suffering from a long-standing hemorrhagic syndrome of undetermined origin. This patient appears to have markedly increased thromboplastin inactivator in his serum, but further confirmation of this finding is necessary.

\section{DISCUSSION}

Physiological agents capable of opposing the action of thromboplastin or of causing its inactivation have long been the subject of investigation. Among the first of these studied was heparin. Quick in 1936 (5) found that tissue thromboplastin was unable to counteract the anticoagulant action of heparin, and concluded that heparin did not exert its major action as an antithromboplastic substance. Brinkhous, Smith, Warner, and Seegers in 1939 (6) found that heparin in the presence of its cofactor prevented the conversion of prothrombin into thrombin, but that an excess of tissue thromboplastin could partially overcome this anticoagulant effect. Similar findings were obtained by Dyckerhoff and Marx in 1944 (7). Despite these findings, it is most likely that the action of heparin is primarily antithrombic, and that its apparent antithromboplastin activity results from the prevention of the participation of thrombin in the autocatalytic acceleration of blood coagulation (8).

Perhaps the most extensively studied agent with antithromboplastic activity is the lipid material first described by Tocantins in 1942 (9). In a series of publications covering a period of many years its properties, occurrence, and mode of action have been carefully elaborated (10-18). Since this lipid antithromboplastin is thought to act against cephalin, it has been termed "anticephalin." Anticephalin is present in blood carefully collected in non-wetting containers, and is widely distributed in almost all tissues. It is readily adsorbed on glass and other surface-active materials, and can be concentrated and purified by successive methanol and ether extraction. Anticephalin appears to react directly with thromboplastins of tissue origin and with cephalin, reducing their ability to accelerate clotting in recalcified plasma. According to Tocantins, anticephalin is one of the factors preserving the fluidity of the blood by preventing coagulation in the presence of weak thromboplastic activity. Its action can be overcome by dilution of blood, since it is more susceptible to dilution than are the coagulant substances. It can likewise be made ineffective by contact with an adsorbing surface or overwhelmed by an excess of thromboplastin. A similar substance was described by Overman (19) who concluded that it acted in combination with a protein to form thromboplastin, but that it was anticoagulant if present in excess.

Several groups of investigators have been concerned with plasma proteins capable of inactivating tissue thromboplastin. Schneider (20) was able to identify as thromboplastin a placental toxin which was lethal to mice by the intravenous route. He noted further that this placental thromboplastin gave reduced toxicity and thromboplastic 
activity when incubated with serum, and was able partially to characterize the protein responsible for this thromboplastin inactivation (21-23). Essentially similar results were obtained by Thomas (24) working with brain and lung extracts as the source of thromboplastin. Thomas found that calcium ion was necessary for the thromboplastin inactivator to function most effectively, and that the thromboplastin inhibition was reversible. McClaughry (25) inactivated tissue thromboplastin with serum, and was then able by rapid sedimentation, to obtain a thromboplastic sediment and an anticoagulant supernatant, thus confirming the reversibility of the reaction. In these studies it was also determined that the known clotting factors did not cause thromboplastin inactivation. The more recent studies of Lanchantin and Ware (26) probably deal with similar or identical plasma proteins to those described by earlier investigators. These workers found that incubation of tissue thromboplastin with serum resulted in a progressive loss of thromboplastic activity after a short period of enhanced activity. If the serum had been treated with barium sulfate, this initial hyperactivity was eliminated, and the onset of in- activation was immediate. The reversibility of this reaction, and the need for calcium ions was confirmed. In all these studies on plasma protein inactivators of tissue thromboplastin, essentially similar properties have been described, save for differences in heat lability observed in the various laboratories. Nevertheless, there is no clear evidence in favor of a multiplicity of participating proteins as yet.

An antithromboplastic plasma protein of somewhat different nature has been described by Fiala (27). He noted an anticoagulant in platelet-free plasma which could be inactivated by dilution. This anticoagulant was adsorbed on a variety of surfaces, including glass, kaolin, and celite. However, it was not extractable with ether, in contrast to the agent described by Tocantins. By adsorption of plasma with barium carbonate and subsequent elution with acetic acid, an anticoagulant protein material was obtained which prolonged the clotting time of recalcified plasma, and which could be neutralized with tissue thromboplastin. It was found that this anticoagulant disappeared during the course of clotting.

Two additional types of antithromboplastic

TABLE I

Properties of reported antithromboplastins

\begin{tabular}{|c|c|c|c|c|c|c|c|c|}
\hline References & Nomenclature & Dialyzable & Heat stability & $\begin{array}{c}\text { Ether } \\
\text { extractable }\end{array}$ & $\begin{array}{c}\mathrm{BaSO}_{4} \\
\text { absorbable }\end{array}$ & $\begin{array}{l}\text { Storage } \\
\text { stable }\end{array}$ & $\begin{array}{c}\text { Protein } \\
\text { fraction }\end{array}$ & Source \\
\hline $5-7,32$ & $\begin{array}{l}\text { Heparin and } \\
\text { cofactor }\end{array}$ & Yes & $\begin{array}{l}\text { Heparin stable } \\
\text { cofactor } \\
\text { inactivated } \\
\text { at } 56^{\circ} \mathrm{C} .\end{array}$ & $\begin{array}{l}\text { Heparin no; } \\
\text { Cofactor yes }\end{array}$ & Yes & Yes & $\begin{array}{l}\text { Cofactor in } \\
\mathrm{V} \text { of Cohn }\end{array}$ & $\begin{array}{l}\text { Blood, } \\
\text { tissues }\end{array}$ \\
\hline 9-19 & $\begin{array}{c}\text { Anticephalin; } \\
\text { phosphatide } \\
\text { inhibitor }\end{array}$ & Yes & $\begin{array}{l}\text { Inactivated } \\
\text { at } 65^{\circ} \mathrm{C} .\end{array}$ & Yes & Yes & No & $\begin{array}{c}\mathrm{IV}_{1} \mathrm{~V}_{2+1} \text { of } \\
\text { Cohn }\end{array}$ & $\begin{array}{l}\text { Blood, } \\
\text { tissues }\end{array}$ \\
\hline $21-23$ & $\begin{array}{l}\text { Antithrombo- } \\
\text { plastin, } \\
\text { thromboplastin } \\
\text { inhibitor }\end{array}$ & No & $\begin{array}{l}\text { Inactivated } \\
\text { at } 56-65^{\circ} \mathrm{C} \text {. }\end{array}$ & No & No & Yes & $\begin{array}{l}\text { In } 50 \% \\
\left(\mathrm{NH}_{4}\right)_{2} \mathrm{SO}_{4} \\
\text { precipitate }\end{array}$ & Blood \\
\hline 27 & $\begin{array}{l}\text { Protein } \\
\text { inhibitor }\end{array}$ & & $\begin{array}{l}\text { Inactivated } \\
\text { at } 65^{\circ} \mathrm{C} .\end{array}$ & No & Yes & No & & $\begin{array}{l}\text { Plasma only. } \\
\text { Lost with } \\
\text { clotting }\end{array}$ \\
\hline $28-30$ & Sphingomyelin & & Heat-stable & Yes & Yes & Yes & & Tissues \\
\hline 31 & $\begin{array}{l}\text { Antithrombo- } \\
\text { plastic } \\
\text { protein }\end{array}$ & No & $\begin{array}{l}\text { Destroyed at } \\
65^{\circ} \mathrm{C} \text {. }\end{array}$ & No & Yes & & $\begin{array}{l}{ }^{45-70 \%} \\
\left(\mathrm{NH}_{4}\right)_{2} \mathrm{SO}_{4} \\
\text { precipitation }\end{array}$ & Muscle \\
\hline $\begin{array}{c}\text { Present } \\
\text { report }\end{array}$ & $\begin{array}{l}\text { Thromboplastin } \\
\text { inactivator }\end{array}$ & No & $\begin{array}{l}\text { Partially } \\
\text { destroyed } \\
\text { at } 60^{\circ} .\end{array}$ & No & No & Yes & V of Cohn & Blood \\
\hline
\end{tabular}


agents have been prepared from tissues. These include the sphingomyelin group (28-30), and the antithromboplastic protein obtained from muscle by Dreyfus (31).

In Table I are summarized the properties of the various physiological agents reported to have antithromboplastic activity. The thromboplastin inactivator described in the present report probably differs from any of those previously described. With respect to its activity, it is directed against thromboplastin of blood rather than that of tissue, in contrast to the agents studied in the past. Moreover, the following characteristics serve to differentiate the present agent from those of the other authors: 1) It differs from the heparincofactor system in being nondialyzable, heat-stable at $56^{\circ} \mathrm{C}$. and non-adsorbable on barium sulfate. 2) Unlike the anticephalin lipoid, and the sphingomyelin group of compounds, the thromboplastin inactivator is evidently a protein in the albuminoid group. 3) In contrast to the antithromboplastin of Schneider (20), Lanchantin and Ware (26) and others, the thromboplastin inactivator is active in the absence of calcium ion, and appears to have greater heat stability. 4) The thromboplastin inactivator differs from the protein described by Fiala (27) in that it is not adsorbed on the common adsorbants, it is present in both plasma and serum, and it is highly storage stable.

Because of its slow and progressive action, the thromboplastin inactivator probably functions as a removal mechanism for the blood thromboplastin rather than as an anticoagulant. In this role, its action may be comparable to the fibrinolytic system and to the adsorption of thrombin on fibrinogen. In each case the function of the reaction is the removal of a product of blood coagulation when that product no longer serves a useful physiological purpose. It would appear that the inactivators thus contrast with the anticoagulants which prevent coagulation from taking place too readily.

At present the mechanism of action of the thromboplastin inactivator is a matter of speculation. This must remain the case until there is clarification as to the nature of the thromboplastin formed by the interaction of blood elements. However, it is of interest that the thromboplastin inactivator appears to fall into the same category of proteins as do certain antithrombins (32).
The possibility is suggested that thrombin may be a component of the thromboplastin complex of blood origin. Were such the case, the thromboplastin inactivation studied herein could result from thrombin inactivation.

\section{SUMMARY}

A factor has been studied which appears to inactivate the thromboplastin formed by the interaction of blood components. Measurement of this thromboplastin inactivator has been accomplished by means of the "thromboplastin inactivation test." The thromboplastin inactivator is a protein found both in plasma and in serum. It is relatively heat-stable, is not adsorbed on barium sulfate, and is found in fraction $V$ of Cohn. The thromboplastin inactivator differs in properties and function from previously described antithromboplastins; but it has similarities to certain antithrombins. It is suggested that thrombin is a component of the thromboplastin complex, and that the present thromboplastin inactivation represents thrombin inactivation.

\section{REFERENCES}

1. Biggs, R., Douglas, A. S., and Macfarlane, R. G., The formation of thromboplastin in human blood. J. Physiol., 1953, 119, 89.

2. Spurling, C. L., and King, P. D. W., Studies on thromboplastin generation. J. Lab. \& Clin. Med., 1954, 44, 336.

3. Biggs, R., and Douglas, A. S., The thromboplastin generation test. J. Clin. Path., 1953, 6, 23.

4. Cann, J. R., Kirkwood, J. G., Brown, R. A., and Plescia, O. J., The fractionation of proteins by electrophoresis-convection. An improved apparatus and its use in fractionating diphtheria antitoxin. J. Am. Chem. Soc., 1949, 71, 1603.

5. Quick, A. J., On the action of heparin and its relation to thromboplastin. Am. J. Physiol., 1936, 115, 317.

6. Brinkhous, K. M., Smith, H. P., Warner, E. D., and Seegers, W. H., The inhibition of blood clotting : An unidentified substance which acts in conjunction with heparin to prevent the conversion of prothrombin into thrombin. Am. J. Physiol., 1939, 125, 683.

7. Dyckerhoff, H., and Marx, R., Uber Heparinkomplement und eine Methode seiner vergleichenden Bestimmung im Blute. Biochem. Ztschr., 1944, 316, 255.

8. Biggs, R., and Macfarlane, R. G., Human Blood Coagulation and Its Disorders. Springfield, I1linois, Charles C Thomas, 1953. 
9. Tocantins, L. M., Antithromboplastic activity of normal and hemophilic plasmas. Federation Proc., 1942, 1, 85.

10. Tocantins, L. M., Cephalin, protamine and the antithromboplastic activity of normal and hemophilic plasmas. Proc. Soc. Exper. Biol. \& Med., 1943, 54, 94.

11. Tocantins, L. M., Anticephalin activity and the prothrombin conversion rate of normal and hemophilic plasmas. Proc. Soc. Exper. Biol. \& Med., 1944, 55, 291.

12. Tocantins, L. M., Estimation of the anticephalin activity of whole blood. Proc. Soc. Exper. Biol. \& Med., 1944, 57, 211.

13. Tocantins, L. M., Influence of the contacting surface on the coagulability and anticephalin activity of normal and hemophilic plasmas. Am. J. Physiol., 1945, 143, 67.

14. Tocantins, L. M., Relation of contacting surface and anticephalin activity to the maintenance of the fluidity and coagulability of blood. Blood, 1946, $1,156$.

15. Tocantins, L. M., and Carroll, R. T., Separation and assay of a lipid antithromboplastin from human brain, blood, plasma and plasma fractions. Conference on Blood Clotting and Allied Problems, New York, Josiah Macy Jr. Foundation, 1949, Vol. 2, pp. 11-28.

16. Tocantins, L. M., and Carroll, R. T., Distribution and assay of inhibitors and accelerators of blood coagulation in extracts of organs of normal and hemophilic man. Federation Proc., 1950, 9, 127.

17. Tocantins, L. M., Carroll, R. T., and Holburn, R. H., The clot accelerating effect of dilution on blood and plasma. Relation to the mechanism of coagulation of normal and hemophilic blood. Blood, 1951, 6, 720.

18. Tocantins, L. M., Holburn, R. R., and Carroll, R. T., Response of plasma to excess of thromboplastin as a measure of prothrombin activity. Proc. Soc. Exper. Biol. \& Med., 1951, 76, 623.

19. Overman, R. S., The chemical purification and mode of action of a thromboplastic inhibitor. Conference on Blood Clotting and Allied Problems, New York,
Josiah Macy, Jr. Foundation, 1949, Vol. 2, pp. 2950.

20. Schneider, C. L., The active principle of placental toxin: thromboplastin; its inactivator in blood: antithromboplastin. Am. J. Physiol., 1947, 149, 123.

21. Schneider, C. L., A toxic principle from progestational endometrium and placenta. Proc. Soc. Exper. Biol. \& Med., 1946, 62, 322.

22. Schneider, C. L., The inactivation of placental toxin by human serum. Am. J. Physiol., 1946, 146, 140.

23. Schneider, C. L., Placental toxin: inactivation and tolerance during pregnancy. Am. J. Physiol., 1946, 147, 255.

24. Thomas, L., Studies on the intravascular thromboplastic effect of tissue suspensions in mice. II. A factor in normal rabbit serum which inhibits the thromboplastic effect of the sedimentable tissue component. Bull. Johns Hopkins Hosp., 1947, 81, 26.

25. McClaughry, R. I., The specificity of antithromboplastic activity. J. Michigan M. Soc., 1950, 49, 685.

26. Lanchantin, G. F., and Ware, A. G., Identification of a thromboplastin inhibitor in serum and plasma. J. Clin. Invest., 1953, 32, 381.

27. Fiala, S., On the role of a protein inhibitor in the first stage of blood coagulation. Arch. internat. de physiol., 1951, 58, 386.

28. De Sütö-Nagy, G. J., The mode of action of an anticoagulant derived from tissues. Am. J. Physiol., 1944, 141, 338.

29. Trethewie, E. R., Cleland, J. B., and Pengelley, T. J., Anticoagulant liberated from perfused mammalian liver. M. J. Australia, 1947, 1, 321.

30. Hecht, E., New inhibitors of the first stage of the blood-clotting process. Nature, 1951, 167, 279.

31. Dreyfus, J. C., Sur un nouvel anticoagulant extrait du tissu musculaire de lapin. Biochim. et biophys. acta, 1953, 10, 326.

32. Nilsson, I. M., and Wenckert, A., Demonstration of a heparin-like anticoagulant in normal blood. I. Human blood. Acta med. Scandinav., 1954, 150, supp. 297. 